\title{
A pioneering experience in Brazil: the creation of a center for assistance and research for medical residents (NAPREME) at the Escola Paulista de Medicina, Federal University of São Paulo
}

\author{
Universidade Federal de São Paulo, Escola Paulista de Medicina - São Paulo, Brazil
}

\begin{abstract}
The decision to develop a treatment service for medical residents at Escola Paulista de Medicina was influenced by three main factors: the suicide of four young doctors (2 residents) at this institution between 1995 and 1996, a research study that investigated stress among medical residents and the experience of other countries in response to similar problems. NAPREME has the following objectives: to help to reduce stress among residents, stimulate professional and personal development, prevent professional dysfunction and emotional disorders, offer psychological treatment, assess the tutors of residency programmes and develop research programmes to better identify risk factors for emotional problems during the residency period. We hope that by doing this the overall quality of the residency programme will improve, both for the professionals and the patients.
\end{abstract}

UNITERMS: Medical Education. Internship and Residency. Medical Psychology. Professional Stress. Occupational Health.

\section{INTRODUCTION}

$\mathrm{T}$ The occupational health literature suggests that medicine, as a profession, presents certain inherent risks. An important point that needs to be emphasized is that medicine is by its very nature highly anxiety-generating. Indeed, doctors frequently witness scenes that are rarely encountered in other professions during peace-time. This stressful aspect of medicine has been accentuated in recent times by an increase in patient

\section{Address to correspondence: \\ Luiz Antonio Nogueira-Martins \\ NAPREME \\ Rua Borges Lagoa, 426}

São Paulo/SP - Brasil - CEP 04038-033 turnover, greater patient expectations and the precarious conditions encountered in many emergency services in the public sector. These factors have sometimes led to frank hostility on the part of patients or their families.

Various studies ${ }^{1-3}$, have pointed to some characteristics of the practice of medicine which in isolation or in combination, can produce intense emotional feelings. These include:

1. frequent contact with pain and suffering

2. coping with physical and emotional intimacy

3. treating terminal patients

4. coping with difficult patients, such as those who complain, do not comply with treatment, are hostile, self-destructive or chronically depressed

5. coping with uncertainty, limitations of medical knowledge, and a health system that cannot meet the demands and expectations of patients and their families. 
During medical residency, stress reaches its peak ${ }^{4-13}$ due to a series of factors: the transition from being a student to becoming a doctor, feelings of isolation, fatigue, sleep deprivation, overwork and the fear of making mistakes. These are associated with various psychological problems such as depressive states, suicidal ideation, excessive consumption of alcohol, misuse of drugs, chronic anger, the development of a state of bitter cynicism, and the use of ironic or black humour as a psychological defence. The American Medical Association considers medical residents as an at-risk group for emotional disturbance?

\section{PSYCHOLOGICAL AND PSYCHIATRIC MORBIDITY AMONG RESIDENTS}

Depression and sleep deprivation appear to be two of the most significant psychological problems that affect residents and are considered to be the main symptomatic reactions to this period ${ }^{(8)}$. A clinical syndrome, the "house officer stress syndrome" has been described ${ }^{(9)}$. This syndrome is characterized by the following:

1. episodic cognitive disturbances

2. chronic anger

3. cynicism

4. family discord

5. depression

6. suicidal ideation and suicide attempts

7. drug abuse

According to Small ${ }^{(9)}$, the etiological factors for this clinical syndrome are:

1. sleep deprivation

2. excessive workload

3. professional responsibility

4. frequent changes in work conditions

5. competition between colleagues

Studies of depression among residents have shown that up to $30 \%$ of first year residents are depressed and that this depression generally begins during the second month of the residency and worsens up to the eighth month ${ }^{10}$. Thereafter, the prevalence of depression drops to about $22 \%$ in the second year and $10 \%$ in the third year ${ }^{\prime \prime}$. The highest levels of depression are found among residents during attachments to inpatient units, accident and emergency departments and intensive care units ${ }^{11,12}$.

Smith et $\mathrm{al}^{13}$ studied the frequency of sick-leave for emotional disturbances among 50,000 North American internal-medicine residents. The results showed that about $1 \%$ of residents requested or were sent on sick-leave during the residency. The data reveal the following findings about residents who go on sick leave:

1. there was a higher incidence during the first year of the residency

2. there was an increase in sick-leave between 1979-1984

3. the mean period of leave was 6.7 weeks

4. the incidence was twice as high among women

5. $79 \%$ of those who went on sick-leave finished their residency training (but $27 \%$ changed speciality)

6. $10 \%$ left medicine altogether

7. $2 \%$ committed suicide and a further $3 \%$ made a suicide attempt

Commenting on the results of their study, the authors concluded: "during the last five years, internal medicine has lost 47 doctors to other careers and 8 have committed suicide. Although this represents a small percentage of all residents in training during the last five years, it is equivalent to having lost half of a graduation class, without mentioning the incalculable pain that suicide represents to family members and friends."

\section{STRESS DURING MEDICAL RESIDENCY}

The medical residency is a period during which there is much personal development; the resident has to find a balance between curing and caring for people, to cope with feelings of abandonment within the health care system and to establish limits between his personal and professional identity ${ }^{14}$.

Stress during medical residency has been classified into three categories ${ }^{15}$ :

1. professional stress - associated with the process of professionalization and the adoption of the medical role. Professional stress is linked to: the weight of professional responsibility, coping with difficult patients, supervising younger students and other residents, coping with the everexpanding body of medical knowledge and planning one's professional career.

2. situational stress - associated with the peculiarities of medical training such as: sleep deprivation, fatigue, excessive workload, a large number of difficult patients, excessive administrative work, insufficient auxiliary staff and problems related to the quality of teaching and the educational environment. 
3. personal stress - related to individual characteristics and circumstances such as: personality make-up, psychological vulnerability, socioeconomic situation, family problems and life events etc.

These three categories of stress are often interrelated and superimposed. Hence, the stress associated with choice of speciality involves both personal and professional elements, whilst workload and pressure of time could be considered situational, personal or professional stresses.

In a prospective study of stress among residents in 12 different residency programs at the Escola Paulista de Medicina in São Paulo, Brazil ${ }^{16}$, the following aspects of the job were identified as difficult:

1. the number of patients being looked after

2. communicating with patients of low education or socioeconomic level

3. hostile and demanding patients

4. patients who die

5. patients with behavioral alterations

6. breaking bad news

7. ethical dilemmas

8. fear of contracting infectious diseases

In this study the sources of stress identified by the residents were:

1. fear of making mistakes

2. fatigue and tiredness

3. lack of supervision

4. the feeling of being under constant pressure

5. being on-call at night

6. excessive interference on the part of supervising colleagues

7. meeting inner demands (being the perfect doctor who doesn't make mistakes)

8. lack of time for leisure, family, friends and other activities

This and other studies show that residents are subjected to various types of stress during their training and that these stresses may have adverse effects on the quality of care that is given to patients. Studies have shown that programs designed to reduce stress among residents and to meet some of their psychological and health needs can go a long way to improve performance among residents so that they are better able to cope with stress and provide better care to their patients ${ }^{17-31}$.

It was within this context that a program of this type, called NAPREME (Núcleo de Assistência e Pesquisa em Residência Médica), was created at the Escola Paulista de Medicina. Essentially the service aims to prevent emotional disturbances among residents by providing orientation and care both to residents and those who organize and coordinate the residency programs.

\section{OBJECTIVES}

\section{A. General Objectives}

To reduce stress during the residency, promote professional and personal growth and prevent professional dysfunction and emotional disturbances.

\section{B. Specific Objectives}

1. To facilitate the transition from medical student to doctor

2. To identify the emotional difficulties that occur during training

3. To treat residents with emotional disturbances

4. To improve the system of professional qualification

\section{Strategies}

1. To improve divulgence of the service, using pamphlets, lectures and videos

2. To introduce discussion groups, on a weekly basis, where residents can express their difficulties and fears in relation to training and professional activities

3. Individual interviews with all residents (starting with those in the first year) aimed at obtaining information about the experiences and difficulties faced during training

4. Individual treatment - support, counselling and orientation for residents with personal or professional difficulties

5. A consultation service for course organizers and tutors

6. Training for residents' representatives and supervisors

7. The development of research projects into issues concerning mental health and medical residency (for example: the reasons for absences and sick leave, why residents quit the training program, the adaptive mechanisms used by residents and to examine the difficulties faced by specific subgroups such as female residents) 


\section{RESUMO}

A decisão de criar um centro de assistência e pesquisa em Residência Médica na Escola Paulista de Medicina/Universidade Federal de São Paulo foi influenciada por três principais fatores: o suicidio de quatro jovens médicos (2 residentes) nos anos de 1995 e 1996, uma pesquisa sobre fontes de estresse durante o treinamento na Residência Médica nessa instituição e a experiência de outros paises com relação a questōes semelhantes. O Núcleo de Assistência e Pesquisa em Residência Médica (NAPREME) tem como objetivos: contribuir para a redução do estresse do treinamento, promover o crescimento profissional e pessoal dos residentes, prevenir disfunçōes profissionais e distúrbios emocionais, oferecer atendimento psicológico, assessorar os preceptores dos Programas de Residência Médica e desenvolver projetos de pesquisa que identifiquem as dificuldades emocionais que ocorrem durante o treinamento. O objetivo final é aperfeiçoar o sistema de capacitação profissional na Residência Médica, aprimorando a assistência prestada aos pacientes e a qualidade de vida dos profissionais encarregados dessa assistência.

\section{REFERENCES}

1. Nogueira-Martins LA. Consultoria psiquiátrica e psicológica no hospital geral: a experiência do Hospital São Paulo. Revista ABP-APAL 1989;11:160-4

2. Mawardi BH. Satisfaction, dissatisfactions and causes of stress in medical practice. JAMA 1979;241:1483-6

3. McCue JD. The effects of stress on physicians and their medical practice. N Engl J Med 1982;306:458-63

4. Firth-Cozens J. Emotional distress in junior house officers. Br Med J 1987; 285: 533-6

5. Firth-Cozens J. Stress in medical undergraduates and house officers. Br J Hosp Med 1989;41, 161-4

6. Firth-Cozens J. Sources of stress in women junior house officers. Br Med J 1990;302:89-91

7. Tokarz JP, Bremer W, Peters K. Beyond Survival - The challenge of the impaired student and resident physician. Chicago, American Medical Association, 1979,125 p.

8. Butterfield PS. The stress of residency: a review of the literature. Arch Intern Med 1988;148:1428-35

9. Small GW. House officer stress syndrome. Psychosomatics 1981:22:860-9

10. Valko RJ, Clayton PJ. Depression in the internship. Dis Nerv Sys 1975;36:26-9

11. Reuben DB. Depressive symptons in medical house officers. Arch Intern Med 1985;145:286-8

12. Clark DC, Salazar-Gruesco E, Grabler P, Fawcett J. Predictors of depression during the first six months of internship. Am J Psychiatry 1984;141(9):1095-8

13. Smith JW, Denny WF, Witzke DB. Emotional impairment in internal medicine house staff. JAMA 1986;255:1155-8
14. Brent DA. The Residency as a developmental process. J Med Educ 1981;56:417-22

15. Aach RD, Cooney TG, Girard DE et al. Stress and impairment during residency training: strategies for reduction, identification and management. Ann Intern Med 1988;109(2):154-61

16. Nogueira-Martins LA. Residência Médica: um estudo prospectivo sobre dificuldades na tarefa assistencial e fontes de estresse. Tese de Doutoramento. Escola Paulista de Medicina. 1994.

17. Siegel B, Donnely JC. Enriching personal and professional development: the experience of a support group for interns. J Med Educ 1978;53:909-14

18. Berg JK, Garrard J. Psychosocial Support In Residency Training Programs. J Med Educ 1980;55:851-7

19. Borenstein DB, Cook K. Impairment Prevention in the Training Years. JAMA 1982;247(19):2700-3

20. Pfifferling JH. Coping with Residency Distress. Res Staff Physician 1983;29:105-11

21. Ziegler JL, Kanas N, Strull WM, Bennet NE. A stress discussion group for medical interns. J Med Educ 1984;59:205-7

22. Reuben D, Novack DH, Wachtel TJ, Wartman AS. A comprehensive support system for reducing house staff distress. Psychosomatics 1984;25 (11):815-20

23. Rudner HL. Stress and coping mechanism in a group of family practice residents. J Med Educ 1985;60:5646

24. Blackwell B. Prevention of impairment among residents in training. JAMA 1986;255:1177-8

25. Koran LM, Litt IF. House staff well-being. West J Med $1988 ; 148: 97-101$ 
26. Colford JM, Mcphee SJ. The Ravelled Sleeve Of Care. Managing the Stresses of Residency Training. JAMA 1989;261:889-93

27. Bergman AS, Adler R. Support services for pediatric trainees, a survey of training program directors. AJDC 1991;145:1002-5

28. McCue JD, Sachs CL. A Stress Management Workshop Improves Resident's Coping Skill. Arch Intern Med 1991; 151:2273-7
29. Seelig CB. Changes in Resident's Attitudes in Response to Residency Program Modifications: A Prospective Study. South Med J 1992;85(10):972-5

30. Metz WP, Pollack P. Pediatric Resident Support Group. AJDC 1993;147: 781-6

31. Mushin IC, Matteson MT, Lynch EC. Developing. a Resident Assistance Program. Arch Intern Med 1993;153:729-33 